\title{
Renewable Hydrogen Production
}

\author{
A.C. Lloyd, E. Pike, A. Baral
}

This document appeared in

Detlef Stolten, Thomas Grube (Eds.):

18th World Hydrogen Energy Conference 2010 - WHEC 2010

Parallel Sessions Book 4: Storage Systems / Policy Perspectives, Initiatives and Cooperations

Proceedings of the WHEC, May 16.-21. 2010, Essen

Schriften des Forschungszentrums Jülich / Energy \& Environment, Vol. 78-4

Institute of Energy Research - Fuel Cells (IEF-3)

Forschungszentrum Jülich $\mathrm{GmbH}$, Zentralbibliothek, Verlag, 2010

ISBN: 978-3-89336-654-5 


\title{
Renewable Hydrogen Production
}

\author{
Alan C. Lloyd, Ed Pike, and Anil Baral
}

\begin{abstract}
The need for renewable energy in an environmentally constrained world leads us to examine the potential role of hydrogen produced from renewable sources. Rationales for renewable hydrogen include climate, local air quality, and sustainability goals. Hydrogen can be produced from a variety of current and potential new future renewable resources for applications including transportation and electricity generation. We also examine the effectivenss of a number of policies that have been implemented or adopted. These policies range from specific standards for renewable hydrogen production to broader policies to increase renewable energy or reduce GHG more broadly.
\end{abstract}

\section{Copyright}

Stolten, D. (Ed.): Hydrogen and Fuel Cells - Fundamentals, Technologies and Applications. Chapter 23. 2010. Copyright Wiley-VCH Verlag GmbH \& Co. KGaA. Reproduced with permission. 